\title{
ROAD TO EARTHQUAKE MITIGATION: LESSON LEARNT FROM THE YOGYAKARTA EARTHQUAKE 2006
}

\author{
Subagyo Pramumijoyo*1 \\ ${ }^{1}$ Department of Geological Engineering, Gadjah Mada University, Yogyakarta, Indonesia
}

\begin{abstract}
At early in the morning of May 27, 2006, people of Yogyakarta was stroke by earthquake and mostly heavily damaged building are in lowland or Yogyakarta depression where is occupied by the Young Merapi sediments. The magnitude of earthquake is $M w=6.2$ and USGS rapid moment tensor shows that this earthquake was due to strike-slip fault movement.

Seismic history of Yogyakarta area shows that Yogyakarta was stroke by several earthquakes with different epicenter location. At least two earthquakes stroke the area, that is in 1876 and 1943. The damages are similar to the damages of actual earthquake. Yogyakarta depression is mostly covered by Young Merapi sediments that consist of tuff, volcanic ash, breccias, agglomerate and lava with Quaternary in age. The thickness of this sediment is up to $100 \mathrm{~m}$.

Our reactive work was to establish firstly zone of damage. For this purpose, we made aerial photograph along the most damaged area. In the same time one of our teams go to the field to measure the cracks, and the other teams to observe liquefaction, hydro geologic measurement, and observation on landslide induce by earthquake. Secondly, we must understand the soil properties and its thickness, because in seismic history it was a similar damage on the same area due to earthquakes however the earthquake epicenters were different. For this purpose we utilize the method of micro-tremors. We also made some
\end{abstract}

${ }^{*}$ Corresponding author: S. PRAMUMIJOYO, Department of Geological Engineering, Faculty of Engineering, Gadjah Mada University, Jl. Grafika 2 Yogyakarta, 55281, Indonesia. E-mail: bagyo@ugm.ac.id drilling until $60 \mathrm{~m}$ each, measuring seismic velocity on bore hole, and magneto telluric measurement. We also have helped by Kyushu University in installing micro seismic net work. The research was followed by either undergraduate and graduate students. Fortunately our research was financed by AUN/Seed Net - JICA. Some of the results were published in a book entitled The Yogyakarta Earthquake of May 27, 2006. Another outcome is the Maps of Microzonation and Earthquake Hazard of Bantul Area that dedicated to Bantul people.

Based on aerial photograph observation and field observation on Bantul Regency, especially along the Opak River, and to Wonosari to the East, there was no surface ruptures, so there is no fault on surface. Interpretation of aftershock data was showing the difference cluster. There is still open problem in determining either epicenter or aftershock location. The damage building was interpreted as due to its geologic setting, non engineered building, and close to epicenter of earthquake. This heavily damaged building are located on the Young Merapi sediments at Bantul Regency and lake deposits at Gantiwarno and Bayat area where it can amplify the surface seismic wave. It implies that Peak Ground Acceleration according to Indonesian National Standard should be modified in Yogyakarta area.

Keywords: Earthquake, seismic, epicenter, microtremor, microzonation.

\section{Introduction}

On Saturday morning of May 27, 2006, at 5:53:59 AM Yogyakarta was stroke by earthquake According to United States Geological 
Survey (USGS) this earthquake epicenter located at $25 \mathrm{~km}$ south-south east of Yogyakarta with Mw: 6.2, but according to Indonesian Meteorological and Geophysical Agency (BMG) the epicenter is located at $40 \mathrm{~km}$ south of Yogyakarta with 5.9 Richter scale. USGS rapid moment tensor shows that this earthquake was due to strike-slip fault movement.

This earthquake is not great earthquake however it has resulted 5,048 victims, 19,401 serious injuries, 8,437 minor injuries, 487 paralyzed and 430,374 houses were damaged. The total cost of lose is Rp 29,1 trillion with currency: US\$ 1.- = Rp. 9000.- (Yuswantana et al., 2007). In fact it is not the first time Yogyakarta was stroke by earthquake. According to Newcomb and McCann (1987) there were some great earthquakes stroke Yogyakarta, there are: in January 4, 1840; June 10, 1867; and March 28, 1875 and resulted from multi sources. The 1840 event had very localized tsunami area and in Yogyakarta may be felt earthquake with MMI > VIII, possibly an epicenter on the sea or inland epicenter near coast line so that landslides occurred on steep coast and resulted a small tsunami. The 1867 event was no tsunami and indicate inland epicenter. This event heavily damaged building and in Yogyakarta felt earthquake with MMI > VIII. The 1875 event was similar with the 1867 event, but Yogyakarta only stroke by earthquake with MMI = V-VII. No tsunami was reported in this event. According to Visser (1922 vide Husein et al., 2007) the 1867 event resulted 5 victims and 372 heavily damaged building including the water castle that the ruin is still exist until now. In 1943, it was earthquake that resulted in Bantul regency, 31 victims, 564 injuries, and 2.682 damaged building (van Bemmelen, 1949).

The increase number of victims and damage building is showing ignorance of people to the impact of the earthquakes, it is also means that people ignore the geology of the area and it ignore the environment where they live in. Based on this fact the Geological Engineering Department, Faculty of Engineering, Gadjah Mada University would like to mitigate earthquake in order to minimize the victim together with other disciplines (Karnawati et al., 2007a), start- ing since the emergency perceptive phase of Disaster Cycle (Sutaryo, 2007)

\section{Geology of Yogyakarta area in brief}

Yogyakarta is located in a depression which is on the west limited by Kulon Progo Mountains and to the east bounded by Southern Mountains.

Geology of Kulon Progo Mountains consist of Nanggulan Formation that consists of sandstone with lignite intercalation, sandy marls and claystone with limonite concretion and intercalation with marls and limestone, sandstone and tuff, with Eocene in age. This formation was covered unconformable by Old Andesite Formation that consists of andesitic breccias, tuff, lapilli tuff, agglomerate and andesitic lava intercalation. The age of this formation is Oligocene-Early Miocene. This formation was covered unconformable by Jonggrangan Formation that consists of conglomerate, tuffaceous marl, calcareous sandstone with lignite intercalation, bedded limestone and coral limestone, with Middle Miocene in age. This formation is overlain by Sentolo Formation that consists of limestone and marly sandstone. The Sentolo Formation spread along the lower hills surrounding Progo River, east of the Mountains with age of Middle Miocene - Pliocene.

To the east, the Southern Mountain consist of: Semilir Formation that consists of tuffaceous breccias, pumiceous breccias, dasitic tuff, andesitic tuff and tuffaceous claystone with age of Oligo-Miocene; Nglanggran Formation that consist of andesitic breccias, agglomerate, lava and tuff of Early Miocene; Sambipitu Formation that consists of tuff, shale, siltstone, sandstone and conglomerate of Middle Miocene; Wonosari Formation that consists of coral limestone, calcarenite and tuffaceous calcarenite with Early Miocene - Pliocene in age; Kepek Formation that consists of marl and bedded limestone of Pliocene in age.

Yogyakarta depression is mostly covered by Young Merapi sediments that consist of tuff, volcanic ash, breccias, agglomerate and lava with Quaternary in age. The thickness of this sediment is up to $100 \mathrm{~m}$ (Hendrayana, 1993). 
River and coastal sediments consist of gravel, sand, silt, and clay with age of Holocene (Rahardjo et al., 1995).

The Quaternary sediment is loose sediments comparing to the "bed rock", sediment up to Pliocene age. In theory, when surface seismic wave pass trough a loose sediment its velocity should be decrease but its amplitude should be increase so that the building on the loose sediment should be more shaking than on the basement.

On the geological map of Yogyakarta quadrangle it is a fault system at the border east of depression, that is striking NNE-SSW Kali Opak sub surface fault system. This fault was interpreted from its gravity pattern (Untung et al., 1973). On the seimotectonic map (Kertapati et al., 1992), this fault is an active fault but without its kinematics. The fault system that was interpreted by Rahardjo et al. (1995), was completed by Sudarno (1997). On the depression of Yogyakarta, McDonald (1985, vide Hendrayana, 1993) by its bore hole and geoelectricity, interpreted some subsurface faults striking N-S and E-W. With additional borehole data on the site of damaged it was reinterpreted existing sub-surface faults of South Yogyakarta depression (Karnawati et al., 2007b). It is not only N-S and E-W directions but also NW-SE and NE-SW directions.

\section{Impacts of earthquake}

Heavily damage area spreads along Pundong and Imogiri that striking NE-SW coincide with line of Opak river (Eastern Bantul Regency), and at Gantiwarno and Bayat, that located along E-W line, north of Southern Mountains. The damaged area is on scattered area in east Bantul Regency.

The cracks that have found are mostly on the asphalted streets with various directions and kinematics, however statistically showing the NE-SW direction is dominant (Jayanto, 2007). The length of the cracks is up to $8 \mathrm{~m}$ but if building on the tips of the cracks should be damaged (Pramumijoyo and Sudarno, 2007). There is also crack on the ground either on the different elevations due to gravity or due to liquefac- tion. Liquefaction can be found at Berbah and Imogiri (Eastern Bantul Regency) and was reported also at Gantiwarno. Dry digging well is also found, due to liquefaction.

The earthquake and its aftershock can make a rock fall along the escarpment west and north of Southern Mountain. At Sengir, Prambanan, it can be found subsidence along $150 \mathrm{~m}$ and $25 \mathrm{~m}$ wide (Karnawati, 2007). At Cermai cave, beside toppling on its escarpment is also cracking in side the cave (Yudistira , 2007).

Based on BMG announcement on local newspaper, aftershocks distribution clustered along the Opak River, but according to the result of Kyushu University, Japan, the aftershocks was spreading along NNE-SSW line, approximately $10 \mathrm{~km}$ to the east of Opak River (Fukuoka et al., in prep).

On the Southern Mountain, at Ngalang River there is ground water level drops that made the digging well become dried. This phenomenon is different from those of liquefaction. We believe that there is also change of ground water content, but unfortunately after earthquake the data is not finished yet.

\section{What we have done}

Firstly, we should know the damage that not all of building was damaged. In order to understand the distribution of housing damage and to look at the major crack or surface rupture we made aerial photograph along the most damaged area in collaboration with Geodetic Engineering Department, Faculty of Engineering, University of Gadjah Mada. In the same time one of our teams went to the field to measure the cracks, and the other teams either to the field to observe the landslides induced by earthquake or to observe liquefaction and its hydrogeology. During this period we must explain some phenomena of earthquake to panicking people. For this purpose we have filled an on air interactive program either on the radio or television and published an earthquake poster. Facing and explaining to panicking people was really another problem for us and we consult to Faculty of Psychology, University of Gadjah Mada. And the mobile phones of our faculty 
staffs were opened to answer question from the people.

Secondly, we must understand the soil properties and its thickness, because in seismic history it was a similar damage on the same area due to earthquakes however the earthquake epicenters were different. There is scattered soil in Yogyakarta depression. To know the dimension of soil we need a tool to map the soil. We already know that earthquake surface wave will be amplified if its pass through loose soil. For this purpose we utilize the method of micro-tremors that offered by BPPTK, Yogyakarta. To check the thickness of subsurface data of micro-tremor and to add soil data we also made some drilling until $60 \mathrm{~m}$ each. We have done in collaboration with Civil and Environmental Engineering, Faculty of Engineering, University of Gadjah Mada. We are also measuring seismic velocity on bore hole in collaboration with ESDM and ITB. Beside these methods, we need also magneto telluric method to recognize the present of fault in collaboration with Physical Department, UGM. We also have helped by Kyushu University in installing micro seismic net work. Fortunately our research was financed by AUN/Seed Net - JICA. The research was followed by either undergraduate and graduate students. Two of AUN/Seed-Net doctoral students are still working in the earthquake topics that are Mr. Myo Tanth and Mr. Tun Naing from Myanmar.

Based on multidiscipline approach and due to hard work of Robert Anderson from California Seismic Safety Commission we can publish in 2008 a book entitle The Yogyakarta Earthquake of May 27, 2006, and we also can published the Maps of Microzonation and Earthquake Hazard of Bantul Area that dedicated to Bantul people.

\section{Follow up action}

Based on aerial photograph observation and field observation on Bantul Regency, especially along the Opak river, and to Wonosari to the East, there was no surface ruptures, so there is no fault on surface The interpretation is that earthquake was not tearing the surface but sub surface only. Interpretation of aftershock data was showing the difference cluster between Wagner et al. (in prep) that located at $15 \mathrm{~km}$ east of Opak River, Fukuoka et al. (in prep.) that located at $10 \mathrm{~km}$ east of Opak River and BMG in Kedaulatan Rakyat (2006) located along Opak River. There is still open problem in determining either epicenter or aftershock location.

The damage building was spotted but clustered at Imogiri - Pundong - Sewon Districts, Bantul Regency, and at Gantiwarno - Bayat Districts, Klaten Regency. It was interpreted as due to its geologic setting, non engineered building, and close to epicenter of earthquake. This heavily damaged building are located on the Young Merapi sediments at Bantul Regency and lake deposits at Gantiwarno and Bayat area where it can amplify the surface seismic wave, so that the waves can damage non engineered buildings.

It implies that Peak Ground Acceleration according to Indonesian National Standard should be modified in Yogyakarta area. Mr. Tun Naing, doctoral student from Myanmar, is studying the problem of soil properties in relation with amplification of surface seismic waves and the result should be modified the Peek Ground Acceleration according to Indonesian National Standard into greater scale. Mr. Myo Tanth, another doctoral student from Myanmar, wills approaching the seismic hazard of Yogyakarta area with Probabilistic Seismic Hazard Assessment.

For the following years, the open problem of Yogyakarta earthquake attracts some scientists to cooperate with us, such as from University of East Anglia, UK, under direction Dr. Paul W. Burton with financial support from British Council, from San Diego State University, USA, under direction of Dr. Eric Frost with support of California Seismic Safety Commission, and of course from Japan Supported Universities that is: Kyushu University (coordinator), Kyoto University, and Hokaido University, and also from MI AUN/Seed-Net that supported by JICA. 


\section{Acknowledgement}

The author would like to thanks to all participants who were taking the data on the field.

\section{References}

Fukuoka, K., Ehara, S., Fujimitsu, Y., Udi, H., Setyawan, A., Setyadji, L. D., Harijoko, A., Pramumijoyo, S., Setiadi, Y., and Wahyudi, in prep. 2008, Interpretation of the 27 May 2006 Yogyakarta Earthquake Hypocenter and Subsurface StructureDeduced from the Aftershock and Gravity data. In The Yogyakarta Earthquake of May 27, 2006. Ed. by Karnawati, D., Pramumijoyo, S., Anderson, R., and Husein, S. Star Publishing Company, Inc., Belmont, USA.

Hendrayana H., 1993, Hydrogeologie und Grundwasssergewinnung im Yogyakarta Becken, Indonesien. Doktors der Naturwissenschaften genehmigte Dissertation, Technischen Hochschule Aaachen, 117 p.

Husein, S., Pramumijoyo, S., Naing, T., Tanth, M., and Murjaya, J., 2007, A Short Note on the Seismic History of Yogyakarta Prior to the May 27, 2006 Earthquake. In The Yogyakarta Earthquake 2006, Ed. by Karnawati, D., Pramumijoyo, S., and Husein, S., published by the Geological Engineering Department, Faculty of Engineering, University of Gadjah Mada.

Karnawati, D., 2007, Eartquake Induced Landslide at Sengir, Prambanan District, Yogyakarta. In The Yogyakarta Earthquake 2006, Ed. by Karnawati, D., Pramumijoyo, S., and Husein, S., published by the Geological Engineering Department, Faculty of Engineering, University of Gadjah Mada.

Karnawati, D., Pramumimoyo, S., and Husein, S., (ed.), 2007a, The Yogyakarta Earthquake 2006. Published by the Geological Engineering Department, Faculty of Engineering, University of Gadjah Mada.

Karnawati, D., Husein, S., Pramumijoyo, S., Ratdomopurbo, A., Watanabe, K., and Anderson, R., 2007b, Earthquake Microzonation and Hazard Maps on Bantul Area, Yogyakarta, Indonesia. In The Yogyakarta Earthquake 2006, Ed. by Karnawati, D., Pramumijoyo, S., and Husein, S., published by the Geological Engineering Department, Faculty of Engineering, University of Gadjah Mada.

Jayanto, G.D., 2007, Genesa Rekahan pada Permukaan Tanah Akibat Gempabumi 27 Mei di Daerah Bantul. Skripsi di Jurusan Teknik Geologi FT UGM.
Kertapati, E. K., Soehaemi, A. dan Djuhanda, A., 1992, Peta Seismotektonik Indonesia. Pusat Penelitian dan Pengembangan Geologi, Bandung.

Newcomb, K. R. and McCann, W. R., 1987, Seismic History and Seismotectonics of the Sunda Arc. Journal of Geophysical Research, vol. 92, no. B1, pp 421-439. American Geophysical Union.

Pramumijoyo, S. and Sudarno, Ign., 2007, Surface Cracking due to Yogyakarta Earthquake 2006. In The Yogyakarta Earthquake 2006, Ed. by Karnawati, D., Pramumijoyo, S., and Husein, S., published by the Geological Engineering Department, Faculty of Engineering, University of Gadjah Mada.

Rahardjo W., Sukandarrumidi dan D. Rosidi, H. M., 1995, Peta Geologi Lembar Yogyakarta, Jawa. Pusat Penelitian dan Pengembangan Geologi, Bandung.

Sudarno, Ign., 1997, Kendali Tektonik Terhadap Pembentukan Struktur pada Batuan Paleogen dan Neogen di Pegunungan Selatan, Daerah Istimewa Yogyakarta dan Sekitarnya. Thesis Magister Program Studi Geologi, Institut Teknologi Bandung, $167 \mathrm{p}$.

Sutaryo, 2007, Health Isssues Relating to National Disaster. In The Yogyakarta Earthquake 2006, Ed. by Karnawati, D., Pramumijoyo, S., and Husein, S., published by the Geological Engineering Department, Faculty of Engineering, University of Gadjah Mada.

Untung, M., Ujang, K. dan Ruswandi, E., 1973, Penyelidikan gaya berat di daerah YogyakartaWonosari, Jawa Tengah. Publikasi Teknik Seri Geofisika, no. 3, Direktorat Geologi Bandung

Van Bemmelen, R.W.,1949, The Geology of Indonesia vol. I A. Martinus Nijhoff, The Haque.

Wagner, D., Rabbel, W., Luehr, B.-G., Wasserman, J., Walter, T. R., Kopp, H., Koulakov, I., Wittwer, A., Bohm, M., Asch, G., and MERAMEX Scientists, in prep. 2008, Seismic Structure of Central Java. In The Yogyakarta Earthquake of May 27, 2006. Ed. by Karnawati, D., Pramumijoyo, S., Anderson, R., and Husein, S. Star Publishing Company, Inc., Belmont, USA.

Yudistira, A.S.A. , 2007, Analisa Rekahan dan Gelombang Permukaan Gempabumi Yogyakarta 27 Mei 2006. Skripsi di Jurusan Teknik Geologi FT UGM.

Yuswantana, B., Harwani, A., Prijambodo, Sulistyo, and Wahyudi, S., 2007, Saiyeg Saeka Kapti, Refleksi Satu Tahun Gempa Yogyakarta. Pemerintah Provinsi DIY, Kepatihan, Danurejan, Yogyakarta. Http//bmg.go.id

Http// USGS. Gov./ NIEC 